\title{
Review of three-phase inverters control for unbalanced load compensation
}

\author{
Raef Aboelsaud 1, A. Ibrahim², Alexander G. Garganeev ${ }^{3}$ \\ ${ }_{1,2}$ Department of Electrical Power and Machines Engineering, Zagazig University, Egypt \\ ${ }^{1,2,3}$ Department of Electrical Engineering, National Research Tomsk Polytechnic University, Russia
}

\begin{tabular}{l}
\hline Article Info \\
\hline Article history: \\
Received May 5, 2018 \\
Revised Oct 29, 2018 \\
Accepted Dec 11, 2018 \\
\hline
\end{tabular}

Keywords:

Control

Inverter

Load unbalances

Microgrid

\begin{abstract}
In the microgrid systems, three-phase inverter becomes the main power electronic interface for renewable distributed energy resources (DERs), especially for the islanded microgrids in which the power quality is easily affected by unbalanced and nonlinear loads, this is due to the fact that the voltage and frequency of the microgrid are not supported by the main power grid but determined only by the inverters. Therefore, the compensation of the load unbalances and harmonics in autonomous microgrid inverters are getting more attention in power quality research areas. The main purpose of this paper is to represent an overview of the control strategies of various inverters for unbalanced load compensation.
\end{abstract}

Copyright (C) 2019 Institute of Advanced Engineering and Science. All rights reserved.

\section{Corresponding Author:}

Raef Aboelsaud,

Department of Electrical Power and Machines Engineering,

Zagazig University, Egypt.

Email: rsahmed@eng.zu.edu.eg

\section{INTRODUCTION}

Today, Renewable Energy Sources (RESs) such as photovoltaic solar systems, wind turbines, fuel cells, hydropower turbines, etc become a part of future power generation systems [1]-[4] which are used in microgrids as Distributed Energy Resources (DERs) and their applications are promising approaches to cope with the environmental and technical problems. Many researches are presented for developing microgrids to enhance energy efficiency, improve power quality, reduce transmission losses, and decrease consumer prices [5]-[7].

Microgrids can be classified into two main classifications: grid-connected microgrids and standalone microgrids [8]. The grid-connected microgrid can operate either a grid-connected mode or an islanding mode [9]. The efficient operation is the key control issue in the grid-connected mode when the main power grid suffers from abnormal conditions the microgrid is converted to the islanding mode and the voltage and frequency control become the main issue in this mode. On the other hand, the standalone microgrid is always operating in the islanding mode without connecting with the main power system because it is usually installed in the remote areas such as mountainous areas or island without the power grid [10].

The DERs include prime movers and conversion interfaces. The output of the prime movers is DC form (such as PVs, fuel cells, batteries, etc.) or AC form (such as wind generators, microturbine generators) but usually converted to DC format first. The inverters are used as the interfaces between the prime movers and the local AC bus of the microgrid. The main function of the inverters is the power transfer and control.

The power quality in autonomous microgrids can be affected under unbalanced and nonlinear loads, this is due to the fact that the voltage and frequency are not supported by the utility [11]. Unbalanced and harmonic-distorted voltage can cause severe problems on equipment such as vibration, over-voltage, overheat and so on. The problems of low power quality in microgrids can be mitigated by using active power filters 
(APFs) which compensate the load unbalances and harmonics by compensating the negative-sequence and harmonic voltage and currents through coupling transformers [12]. However, it is uneconomic to install extra APFs for each of the DER in microgrid. On the other hand, the inverter for each DER can be used to compensate the load-distortion by means of a proper control [13], [14].

This paper shows an overview of the configurations and the control strategies of three-phase inverters as a par of DERs for load unbalance compensations. The paper is organized as follows. Section 2 gives a comparative review of various inverter topologies used under system unbalancing condition which is followed by a description of available control strategies from the unbalanced load compensation point of view in section 3. Comparative analysis of control structures and some suggestions for the future researches are put forward in Section 4. Some conclusions are given in Section 5.

\section{INVERTER TOPOLOGIES}

In this paper, two commonly used two-level inverter topologies are discussed basing on the number of providing wires.

\subsection{Three-phase three-wire inverter topology}

However, the voltage unbalances and harmonics compensation ability can be achieved by proper control of the 3 leg VSI. This topology is less interesting for the low-voltage distribution networks in which [15] a neutral connection is used to allow the circulation of zero sequence current components. Alternatively one can use the three-leg inverter with a D-Y transformer [16] or zigzag transformer [17] which is heavy and costly and thus not desired in many applications.

The zero sequence current component would be filtered in the zigzag transformer or circulating in the D winding of D-Y transformer and the control circuit of the inverter would only have to compensate the unbalances from negative sequence currents.

\subsection{Three-phase four-wire inverter topology 2.2.1. Capacitor midpoint topology}

Capacitor midpoint topology, shown in Error! Reference source not found., is the simplest topology with the least number of switches. The neutral is connected to the midpoint of the split dc-link capacitors. Another advantage is that this topology acts as three single-phase half-bridge inverters, thus each leg of the inverter of can be controlled independently [18]. The main disadvantage of this topology is in the expensive and large capacitor which is required to achieve equal voltage sharing between the split capacitors [19]. Another weakness with this configuration is that under severe unbalanced and nonlinear conditions, a large neutral current flow through the neutral path and causes a perturbation in the control scheme.

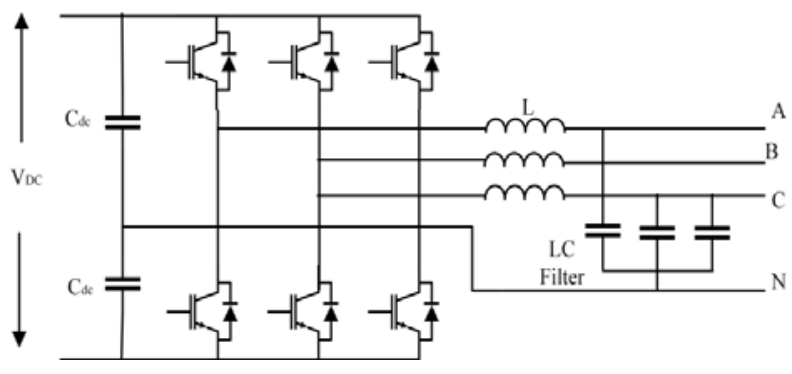

Figure 1. Capacitor midpoint topology

\subsubsection{Three H-bridge inverter}

This type of power converter consists of three single-phase H-bridges to interface with the individual output phases, which are coupled to the loads with an isolation transformer as shown in Error! Reference source not found.. This topology has been proposed for four-wire active power filtering [20], [21]. Compared to the other topologies, this topology has advantages like lower dc-link voltage requirement for a given output voltage, which is half as compared to a capacitor midpoint inverter. Although the higher number of devices is required in this power converter, the output voltage obtained is equivalent to the threelevel inverter resulting in better harmonic profile and reduced requirement for passive filters. Higher 
reliability can be achieved since each phase is independent and during a fault in any one phase, the other two phases can still source power to the grid [22].

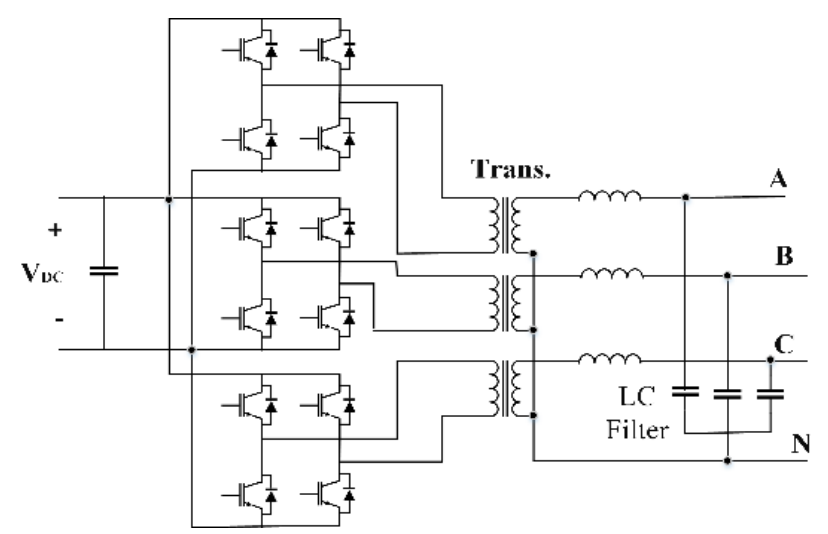

Figure 2. Three-H-bridge inverter

\subsubsection{Four-leg 0202}

In this topology, the neutral line is connecting to the midpoint of the additional fourth leg, as shown in Figure 3. The main advantage of this configuration is that it does not need to utilize large and expensive capacitors and provide lower ripple voltage in the DC-link capacitor [23]. Moreover, the modulation index is about \%15 higher in comparison with the split DC-link [18]. However, The extra two switches are resulting in higher cost more complicated control [24]. The major disadvantage of this topology is the need for isolation transformer(s), which may not be desired in many applications.

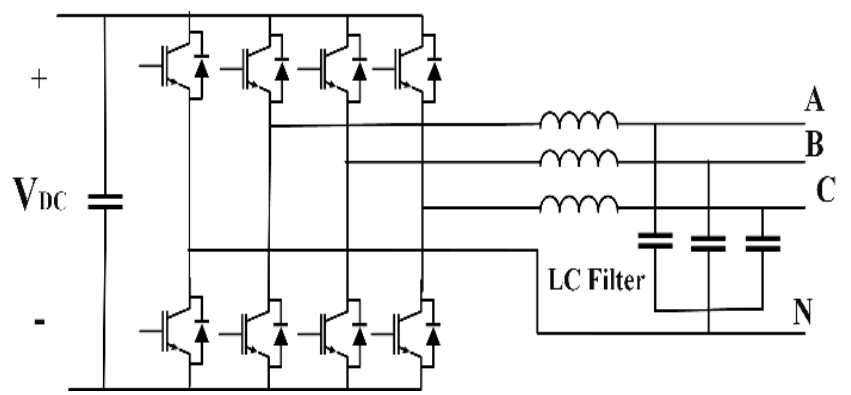

Figure 3. Four-leg inverter topology

\subsubsection{Four leg impedance source inverters (ZSI)}

One of the main limitations of the VSIs is that the DC input voltage must be greater than the peak value of the line-to-line output voltage. So a dc-dc boost converter is needed for all DC prime movers, such as grid-connected photovoltaic (PV) generation and fuel cell power conversion, in which a low-voltage dc source has to be boosted to a desirable ac output voltage [25]. Moreover, Dead time is required to prevent the shoot-through of the switching devices of each inverter leg, this results in distortion in output voltage waveform [26].

These limitations can be solved by the Z-source inverters (ZSIs) [27] in which the dc-dc input stage is replaced with a special LC Z-network as shown in Figure 4. The ZSI can provide output AC voltage greater than the available dc link voltage [28]. The Z-network can boost the dc voltage by means of the shoot-through zero state of the inverter switching cycle in which short-circuit across the dc link is created by closing two switches in one leg simultaneously. In this case, energy is transferred to the Z-network from the capacitors to the inductors, causing a boosting in the dc voltage.

Int J Pow Elec \& Dri Syst, Vol. 10, No. 1, March 2019 : 242 - 255 
The ZSI has some significant drawbacks; namely that in the boost mode makes the input current discontinuous and that large capacitors are needed to sustain a high voltage. The quasi-Z-source inverter (qZSIs) is considered as a solution for this drawbacks [29].

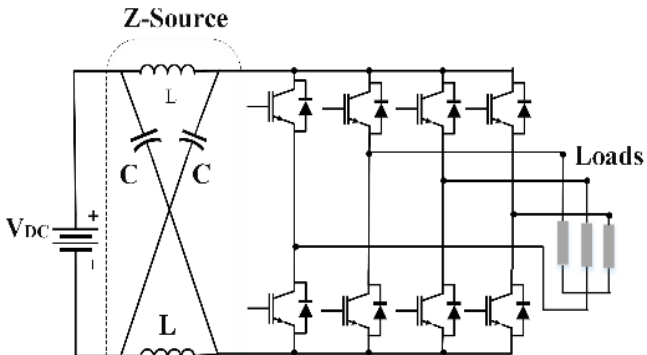

(a)

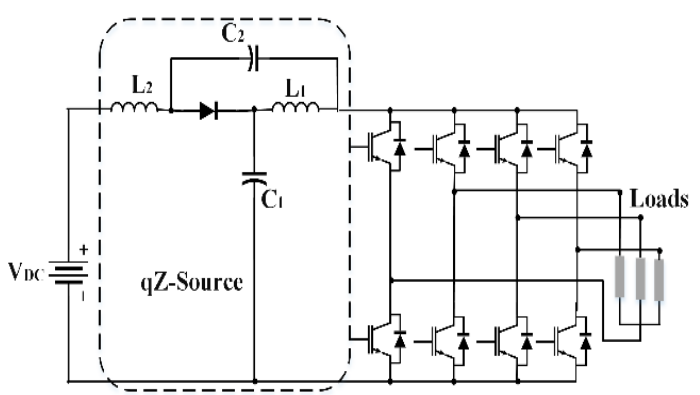

(b)

Figure 4. (a) Z-source four-leg inverter topology, (b) The qZS four-leg inverter topology

\subsubsection{Four leg matrix converter (MC)}

In case of variable speed generation systems, such as variable speed diesel-driven or wind turbine Permanent Magnet Synchronous Generator (PMSG), the generator is connected to a bridge rectifier or a 3-leg VSI as first converting stage and the second converting stage is performed by a 4-leg voltage source inverter (VSI) at the output [30], [31]. The 4-leg VSI is utilized for providing a neutral connection to the load. These two VSIs are presented as 7-leg back-to-back topology which can be replaced by a 4-leg matrix converter (MC), as shown in Figure 5 [32]. This topology provides bi-directional power flow and controllable sinusoidal input/output currents [33]. The absence of the DC Link capacitor is considered as the main advantage of MC making the MC more robust and reliable and saving the space of MC [34], resulting in a better overall efficiency. But the main disadvantage of $\mathrm{MC}$ is that the maximum output voltage is limited to about $87 \%$ of the available input $\mathrm{AC}$ voltage. Moreover, it is particularly sensitive to the disturbances of the input voltage [33].

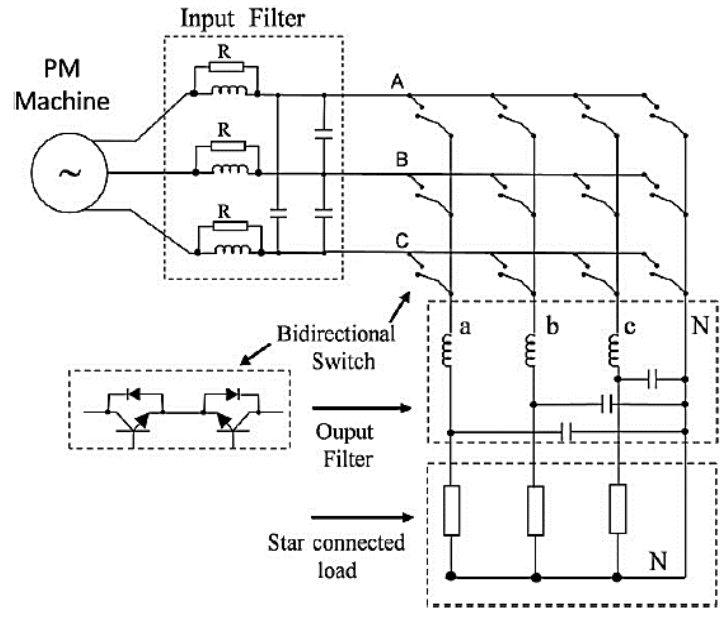

Figure 5. A 4-leg matrix converter

A comparison between the four wire inverter topologies is presented in Table 1. It is generally concluded that each topology has its own advantages and disadvantages, and there is no topology can be used for all applications. 
Table 1. Comparison of three-phase four-wire inverter topologies

\begin{tabular}{|c|c|c|c|c|c|}
\hline & Capacitor midpoint & Four-leg VSI & $\begin{array}{l}\text { Three H-Bridge } \\
\text { Inverter }\end{array}$ & Four leg ZSI & Four leg MC \\
\hline Power conversion & DC-AC & DC-AC & DC-AC & DC-AC & $\mathrm{AC}-\mathrm{AC}$ \\
\hline Isolation transformer & no & no & & no & no \\
\hline No. of switched & 6 & 8 & 12 & 8 & 12 bidirectional \\
\hline Input capacitor size & Very high & medium & low & high & No need \\
\hline $\begin{array}{l}\text { output voltage as a } \\
\text { percentage of input } \\
\text { voltage }\end{array}$ & $\begin{array}{c}<50 \% \text { of input DC } \\
\text { Voltage }\end{array}$ & $\begin{array}{c}<60 \% \text { of input } \\
\text { DC voltage }\end{array}$ & $\begin{array}{c}<100 \% \text { the input } \\
\text { DC voltage }\end{array}$ & $\begin{array}{l}\text { Can be grater or } \\
\text { less than input } \\
\text { DC Voltage }\end{array}$ & $\begin{array}{c}<87 \% \text { of input } \mathrm{AC} \\
\text { voltage }\end{array}$ \\
\hline Design complexity & low & high & medium & high & high \\
\hline Size/wight & medium & low & high & medium & low \\
\hline Application in DER & $\begin{array}{l}\text { Second stage } \\
\text { converter for all } \\
\text { types of DER }\end{array}$ & $\begin{array}{l}\text { Second stage } \\
\text { converter for all } \\
\text { types of DER }\end{array}$ & $\begin{array}{l}\text { Second stage } \\
\text { converter for all } \\
\text { types of DER }\end{array}$ & $\begin{array}{c}\text { Single stage } \\
\text { converter for PV } \\
\text { and fuel cell DER }\end{array}$ & $\begin{array}{c}\text { Single stage } \\
\text { converter for } \\
\text { Variable speed diesel } \\
\text { and wind DER }\end{array}$ \\
\hline
\end{tabular}

\section{CONTROL STRATEGIES UNDER UNBALANCE LOAD CONDITION}

The available control strategies of three-phase two-level inverters for compensating load unbalance in microgrids are illustrated in the following subsections.

\subsection{Symmetrical component based control strategy}

Symmetrical sequence decomposition (SSD) is used mainly in power electric fault analysis [35]. The SSD is able to represent the unbalanced three-phase signal (voltage/current) as a sum of positive, negative and zero sequences. The positive and negative components are three-phase symmetrical signals, whereas the zero sequence is a single-phase one. In terms of controller design, the conventional control strategy uses voltage and current dq0-component in a reference frame rotating at the fundamental frequency $(\omega)$. If the load is balanced, the d- and q-components are dc quantities and the 0-component is absent. Under unbalanced conditions, the negative sequence appears as a disturbance in $\mathrm{d}$ and $\mathrm{q}$ component at a frequency of $2 \omega$. This is because the dq0 reference frame is rotating in the positive direction at an angular frequency of $\omega$, whereas the negative sequence disturbance rotates at an angular frequency of $\omega$ in the opposite direction. In this case, the zero sequence appears at a frequency of $\omega$ in the 0 -component, because the zero-axis is stationary.

In [36], a control strategy based on symmetrical sequence decomposition is proposed to control four-leg inverter. The proposed control method independently regulates the three sequences components of load voltages and currents. Each component is controlled in own dq reference fram as dc signal [37]. Firstly, the symmetrical components of the unbalanced voltages and currents are derived in three channels for each component which is then transferred into the dq reference frame so that the control variables can be adjusted independently in three different sequence components as shown in Figure 6. The first channel controls the positive sequence of voltages and currents in a positive dq ref. frame, which rotates counterclockwise, while the second channel regulates the negative sequence of voltages and currents in a negative reference frame, which rotates clockwise at the same angular frequency. The third channel also compensates the zero sequence voltages and currents in a negative reference frame, this can be done after applying spatially displaced at $120 \mathrm{deg}$. for the zero sequence sequence [38]. Finally, the conventional PI regulators are applied to regulate the voltage and current loops.

The idea of the SSD has been developed using the combination of synchronous and stationary frame control strategy for a four-leg matrix converter in [32]. The suggested scheme is partly similar to the proposed control in a grid-interfacing power quality compensator using three-phase four-leg VSI in [40] and three leg VSI in [41]. In the proposed control strategy, the positive and negative components of the load voltage are regulated without the need of calculation the symmetrical component decomposition. Two synchronous reference frames are used, one is rotating clockwise and the other is rotating counterclockwise in order to control the positive and negative sequence respectively. Two notch filters are used to filter the negative sequence voltages from the positive sequence synchronous rotating frame and the positive sequence voltages from the negative sequence frame as shown in Figure 7. The zero component of the load voltage is regulated by a separate resonant controller $(\mathrm{RC})$ in the stationary frame; while two PI compensators are used for positive and negative sequence voltage regulation.

In [39], four-leg VSI is employed as load unbalance compensator (LUC). The control compensates the unbalancing currents of the standalone microgrid by injecting the unbalance current required for the loads. Each phase current of the microgrid $\mathrm{i}_{\mathrm{mg}} \mathrm{a}, \mathrm{i}_{\mathrm{mg}} \mathrm{b}$, and $\mathrm{i}_{\mathrm{mg}} \mathrm{c}$ is transformed into a rotating $\mathrm{d}-\mathrm{q}-0$ coordinate $i_{\text {mg } d}, i_{\text {mg } q}$, and $i_{\text {mg } 0}$. In this case, the fundamental positive sequence current has DC value while the unbalance current components, positive and negative current sequences, have ac values and are considered as 
harmonics in dq reference frame which are extracted by using low pass filter (LPF) as shown in Figure 8 . In the proposed control system, three PI controllers are used to regulate $\mathrm{d}-\mathrm{q}-\mathrm{0}$ current components.

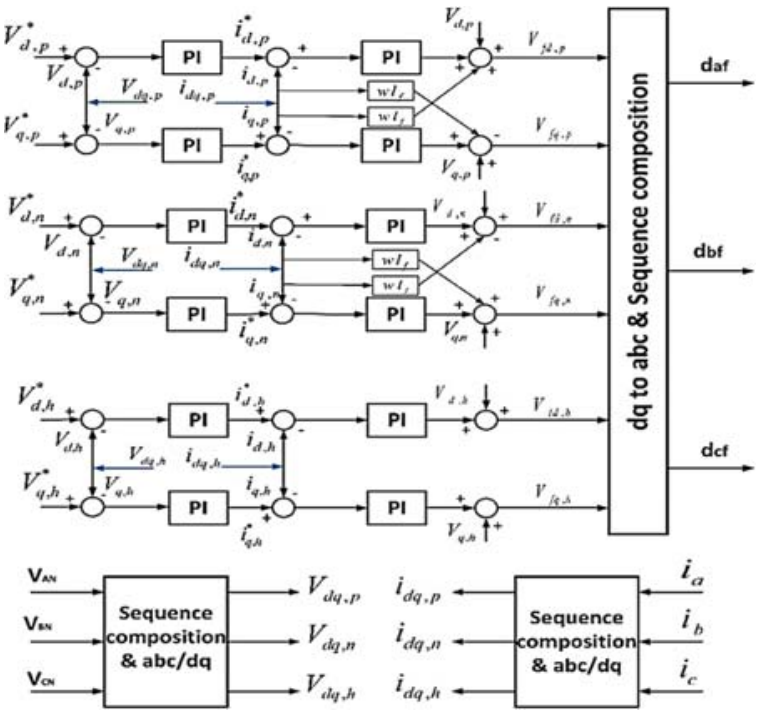

Figure 6. Control strategy based on symmetrical components in [36]

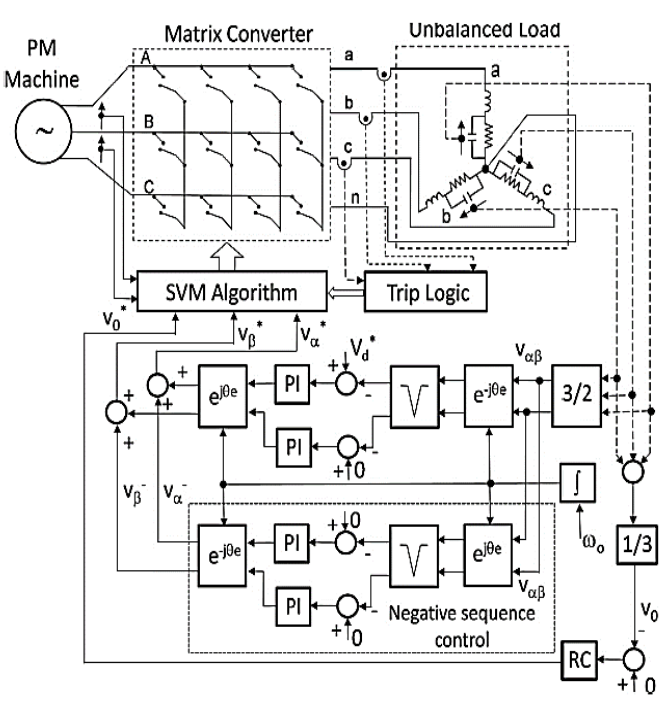

Figure 7. The proposed control strategy for 4-leg $\mathrm{MC}$ in [32]

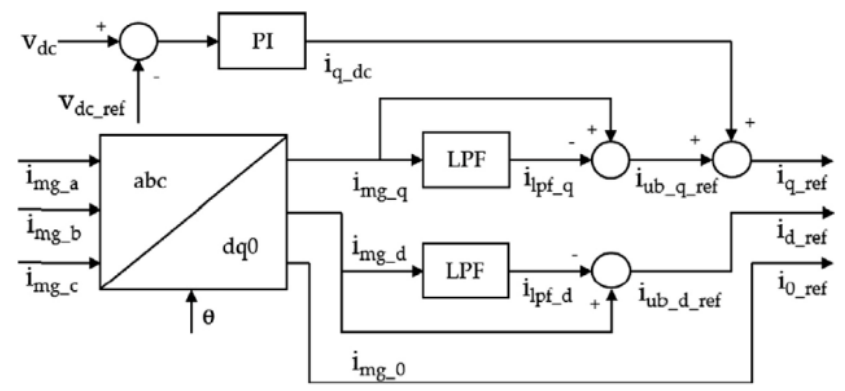

(a)

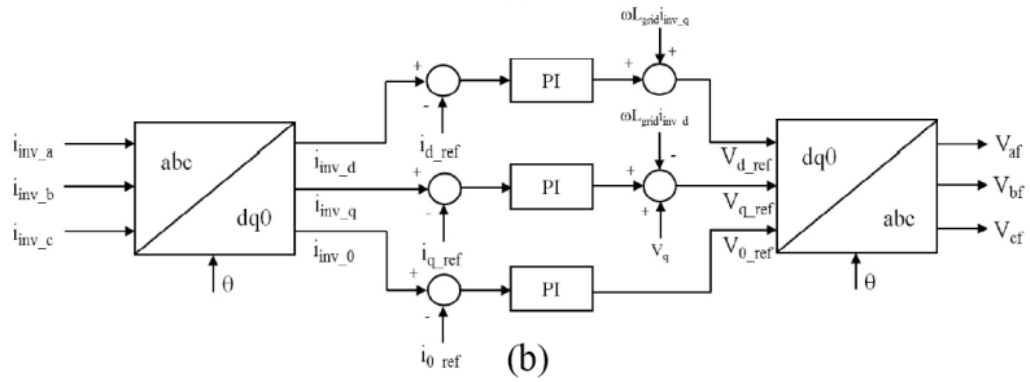

Figure 8. The proposed unbalance compensator in [39] (a) control algorithm, (b) Current controller

Power quality improvement through three-leg VSI based battery inverters in microgrids is proposed in [42]. The proposed control strategy develops an Unbalanced Current (UC) and Harmonic Current (HC) compensation using battery inverters based on the structure of Proportional-Resonance (PR) controller in stationary reference frame [43]. For microgrids, the batteries can be used not only for peak shaping but also for power quality improvement. The transfer function of a PR controller is shown in Figure 9, where $K_{p}$ is the proportional gain and $\mathrm{K}_{\mathrm{ih}}$ is the resonance gain for each harmonic order. The control structure is also shown 
in Figure 9, where only first order and second order controller are drawn. The reference currents of the proposed control ( $i_{\alpha_{-} \text {ref }}$ and $i_{\beta_{-} \text {ref }}$ ) are the negative sequence and harmonic currents of the microgrid in $\alpha \beta$ reference frame. A signal conditioning unit is used to extract theses currents of the microgrid main current as shown in Figure 9.
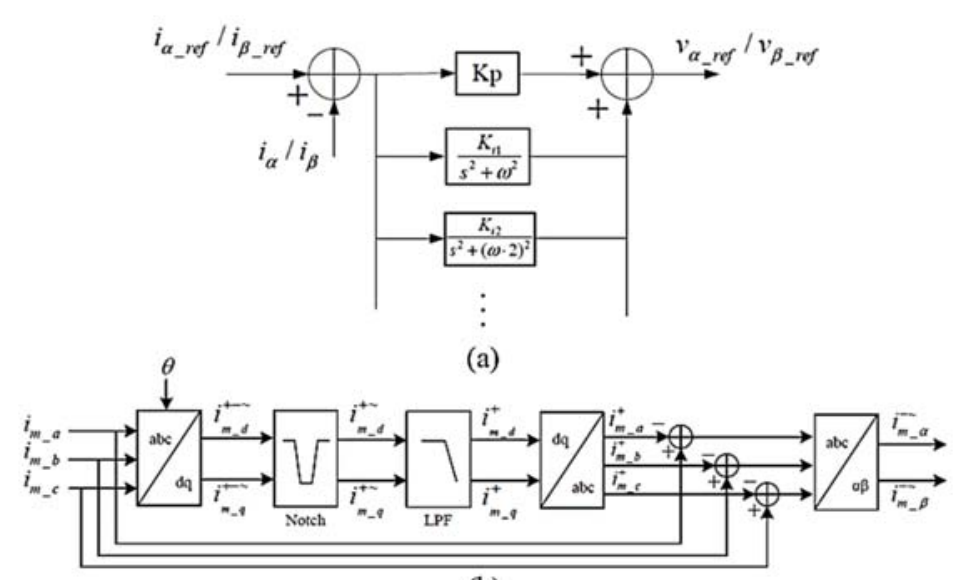

(b)

Figure 9. The proposed control strategy in [42] (a) PR controller structure, (b) signal conditioning unit

In [14], PI and multi-Resonant controller are combined in a single synchronous reference frame (SRF) and used for both the voltage unbalance and harmonic compensation. The fundamental positive sequence (FPS) voltage is converted to 'DC' under the fundamental positive SRF. The fundamental negativesequence voltage is $2 \mathrm{f}_{0}$ ( $\mathrm{f}_{0}$ is the fundamental frequency) 'AC' component under the same SRF. The typical voltage harmonics such as the 5th, 7th, 11th and so on are still 'AC' components under the fundamental positive SRF. The detailed transformed results of each component from 'abc' coordination to the fundamental positive SRF are given in Table 2, where ' + ' and ' - ' means positive-sequence and negativesequence, respectively. The PI controller is responsible to regulate the FPS which is in 'DC' component. On the other hand, the resonant controllers are used to achieve the zero-error tracking on the $2 \mathrm{f}_{0}, 6 \mathrm{f}_{0}$ and $12 \mathrm{f}_{0}$ 'AC' components.

Table 2. Converted results from 'abc' coordination to the fundamental positive SRF

\begin{tabular}{ccccccccc}
\hline & $1 \mathrm{st}$ & $1 \mathrm{st}$ & $5 \mathrm{th}$ & 7 th & 11 th & 13 th & 17 th & $\ldots$ \\
\hline In abc coordination & + & - & - & + & - & + & - & $\ldots$ \\
In positive f0 SRF & 0 & $2 \mathrm{f}_{0}$ & $6 \mathrm{f0}$ & $6 \mathrm{f}_{0}$ & $12 \mathrm{f}_{0}$ & $12 \mathrm{f}_{0}$ & $18 \mathrm{f}_{0}$ & $\ldots$ \\
\hline
\end{tabular}

\subsection{Per phase-based control strategy}

The per-phase control strategy can be only applied on the three phase four wire inverters which provide a neutral connection. Hence, each phase voltage and current can be controlled independently. In [44], a resonant-filter bank in combination with a Proportional $(\mathrm{P})$ controller is utilized to regulate each phase voltage of an autonomous three-phase four-leg inverter [45], as shown in Figure 10. A novel minimum loss discontinuous PWM method based on the Carrier-based 3-D Space Vector PWM is used. A capacitor current feedback loop is added to the control scheme to provide active damping. Furthermore, a voltage feed-forward loop is added to the filter for accurately tracking. This control strategy is also used in [46] without the harmonic frequency resonant filter controllers. 3D space vector PWM in abc coordination is used as PWM technique. 


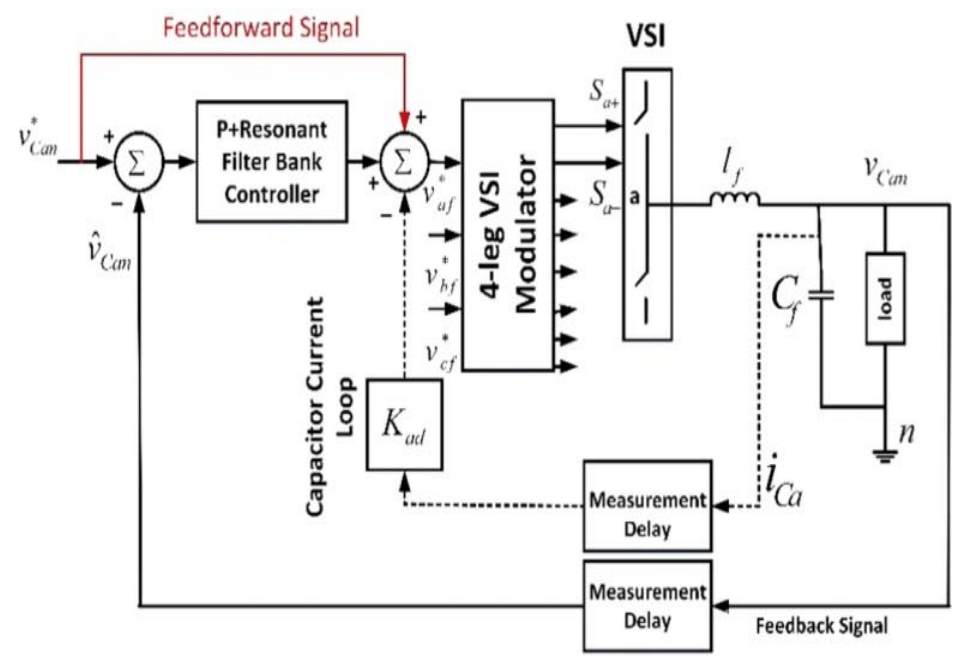

Figure 10. Block diagram of the control system presented by [44]

The work in [31] presents a repetitive control technique of a four-leg matrix converter to mitigate the total harmonic distortion (THD) in the load voltages in case of nonlinear and unbalanced loads. In the proposed control strategy, the repetitive controller is added to the conventional controller $\mathrm{C}(\mathrm{z})$, which can be the PR controller, as shown in Figure 11 where the repetitive controller $(\mathrm{RC}(\mathrm{z}))$ is used for load harmonic compensation, whereas the conventional controller $(\mathrm{C}(\mathrm{z}))$ is used to provide the balanced load voltage for the unbalanced load. Plant phases a, b, and c represent different single phase loads connected to the inverter.

In [48], the hysteresis voltage regulator is employed to control the output voltages of 4-leg VSI. This strategy uses measures the differences between the feedback voltage and the reference value; afterward, this difference is sent to the hysteresis compensator as depicted in Figure 12. Based on this difference and the width of the hysteresis loop the state of switches can be changed. This method is easier to implement than conventional controllers with carrier-based modulation approaches. Nevertheless, it is characterized by the limitation of a non-constant switching frequency, irregular switching and slow dynamic response [49].

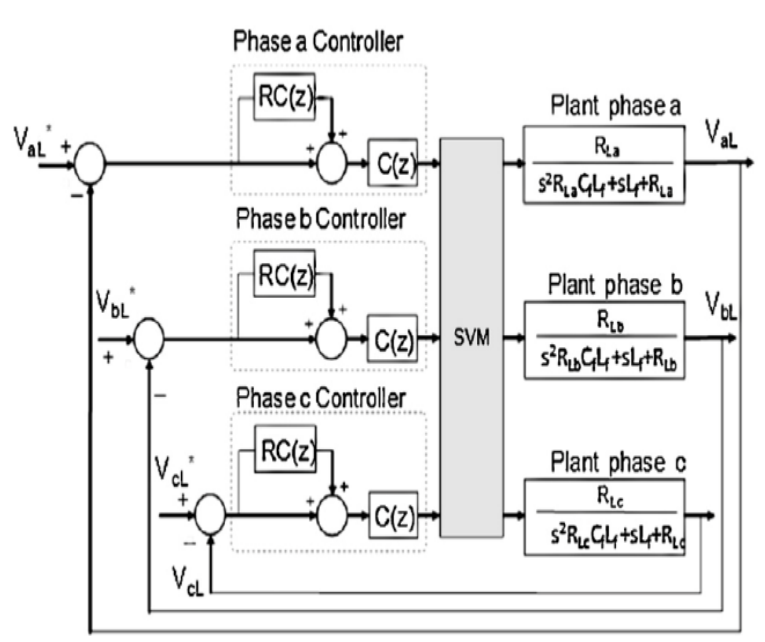

Figure 11. (a)The repetitive control system (b)Three phase control system including the repetitive control topology

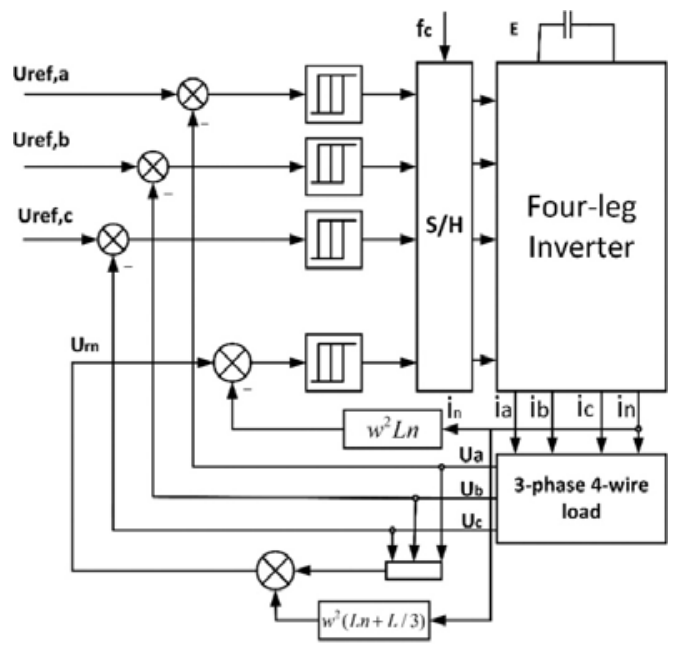

Figure 12. Voltage hysteresis control scheme for the three-phase four-leg inverter 
Authors in [47] suggest an improved per-phase control approach for a four-leg autonomous VSI to regulate output voltage under high unbalanced load conditions [47]. This controller is implemented in three different channels in the dq frame. The structure of the suggested control scheme for the a-phase is presented in Figure. 13. In each phase, the control system consists of voltage and current loops and additional feedforward paths which are employed to decouple the $d$ and $q$ channels from each other. The dq components of each output phase voltage can be determined by applying the Park transformation, after creating the pseudotwo-phase system. The PI controllers are employed in the voltage and current loops.

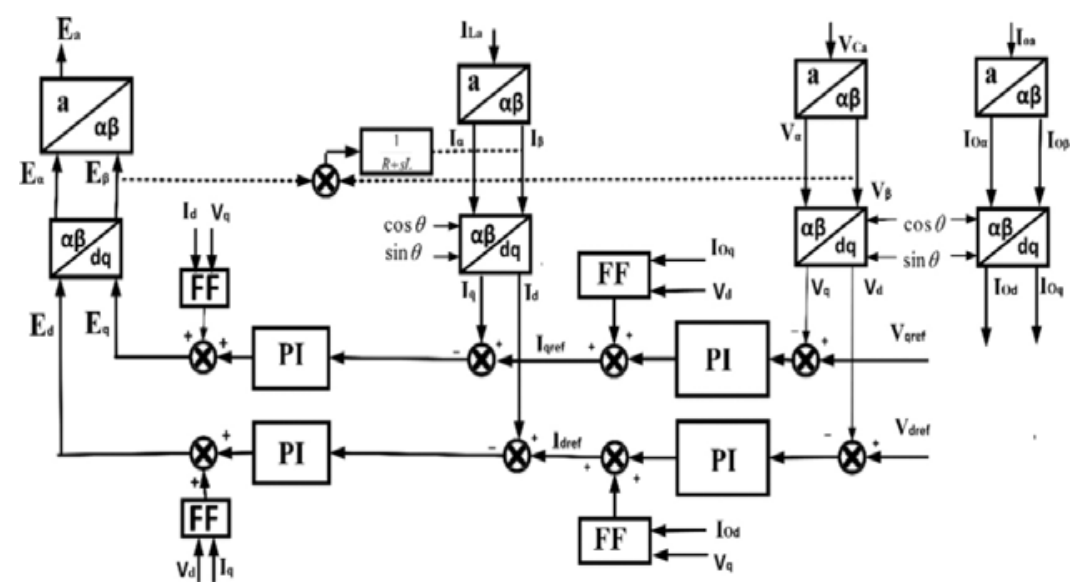

Figure. 13. Schematic diagram of the per-phase control strategy proposed in [47]

\subsection{Alternative control strategies}

The following approaches are based on neither symmetrical components control strategy nor the per-phase control strategy. Hence, these approaches are using other strategies to compensate the system unbalance conditions.

The Model Predictive Control (MPC) is recently considered as one of the most effective ways to control power electronics converters due to its fast response and high control accuracy. The basic idea of this approach is to minimize the predicted error, by evaluating the objective function so that the reference voltages or currents can be tracked accurately under load distortion conditions. A number of studies have been presented under the name of MPC for current control of 4-leg VSI [50], [51], 4-leg ZSI [28], 4-leg qZSI [52], and for voltage control of 4-leg VSI [53].

The work in [54], uses Finite Control Set Model Predictive Control (FCS-MPC) for an autonomous four-leg VSI to maintain balanced output voltages for unbalanced loads with low harmonic distortion for the nonlinear load. Furthermore, The control algorithm is developed to reduce the number of the mathematical operations required for the control system without affecting the control performance. As a result, the size and cost of the microprocessors used for control system implementation are decreased. In this strategy, the two zero vector states are considered as one combined zero vector state and the control algorithm selects between them randomly. Therefore, the control algorithm will require the calculation of 15 states instead of 16 for each sampling period. Moreover, the reference voltage is assumed to be constant through the sampling period. This assumption will eliminate the calculation time required for reference voltage extrapolation. The block diagram of the suggested control scheme is presented in Figure 14. To handle the desired control objectives, the cost function is composed of three cost functions as follows:

$$
g=\left[v^{*}-v_{o}(k+1)\right]^{2}
$$

where $v^{*}$ is the reference output voltage vector and $v_{o}(k+1)$ is the predicted output voltage vector. I $(\mathrm{k})$ and $i o(k)$ are the output inverter current and load current vectors, respectively. The predictive model is used to predict $\mathrm{v}_{\mathrm{o}}{ }^{*}$ for instant $(k+1)$ from the measured values of the load current $i_{0}(k)$ and output inverter current $\mathrm{i}$ at an instant $(k)$. The objective function selects the best switching state according to the error between the reference voltage and the predicted voltage.

Int J Pow Elec \& Dri Syst, Vol. 10, No. 1, March 2019 : $242-255$ 


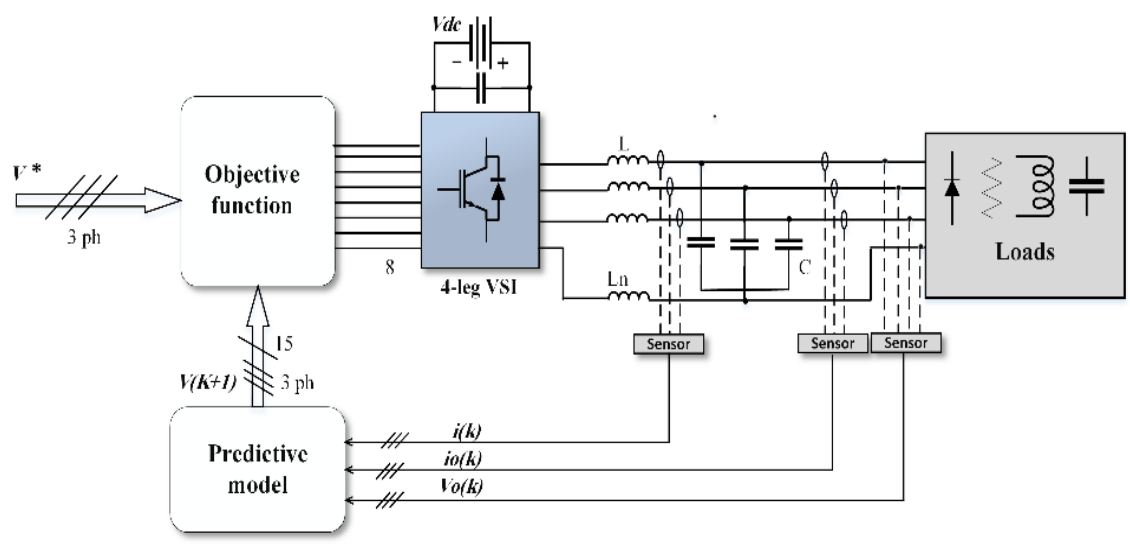

Figure 14. The proposed FCS-MPC scheme for qZS four-leg inverter in [54]

In [55], a novel control strategy is developed for a stand-alone split dc bus VSI. In this control technique, an inner discrete-time sliding mode-controlled (DSMC) current loop with an outer robust servomechanism controlled (RSC) voltage loop is combined as shown in Figure 15. This method is used to achieve voltage regulation with low steady-state error and low total harmonic distortion and fast transient response under various load disturbances and unbalances. The control algorithms are developed under stationary $\alpha \beta 0$ reference frame and a modified space vector pulse width modulation (MSVPWM) is proposed to implement the algorithm under $\alpha \beta 0$ reference frame. After converting the quantities from reference frame into $\alpha \beta 0$ reference frame, applying symmetry of the three dimensions, and conducting per unit transformation, the system model can be reduced into a single-phase per-unit equivalent circuit, and then a state space representation model of the plant is developed. MSVPWM is a modified space vector pulse width modulation inverter, $v_{\text {ref }}$ is the reference load voltage, $i_{c m d} *$ is the desired inverter current command, $i_{c m d}$ is the true inverter current command, $v_{p w m}{ }^{*}$ is the PWM voltage command, $v_{p w m}$ and is the true modulated inverter output voltage. A current limiter is added between the two loops for over-current protection.

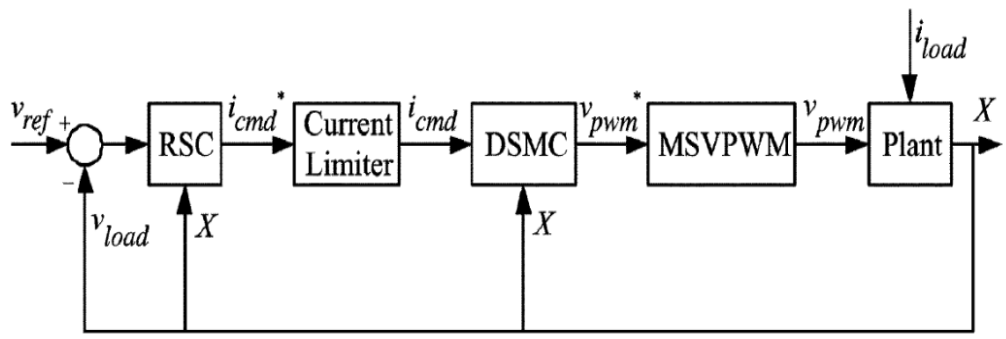

Figure 15. The proposed control system block diagram in [55]

\section{COMPARATIVE ANALYSIS OF CONTROL STRUCTURES}

The control strategies of three-phase inverters can be classified into several categories based on different consideration as shown in Table 3.From the view of modulation, the modulation schemes can be broadly classified as the following: carrier less (hysteresis control and model predictive control) and carrierbased (sinusoidal pulse width modulation (SPWM), Discontinuous PWM (DPWM) [44]) and 3-D space vector modulation (3D-SVM) [24]. However, the carrier-less modulation method provides a fast dynamic response, they cause a variable switching frequency operation. In contrast, the carrier-based methods impose a constant switching frequency operation. The 3D-SVM offers good de bus utilization as well as a lower THD in comparing with the SPWM; these advantages make this method more interesting. However, this method is complex in real-time implementation. The discontinuous PWM (DPWM) is introduced an alternative approach instead of 3D-SVM as it make use of the merits of both PWM and SVM methods. 
Table 3. Comparison of different control strategies in autonomous model

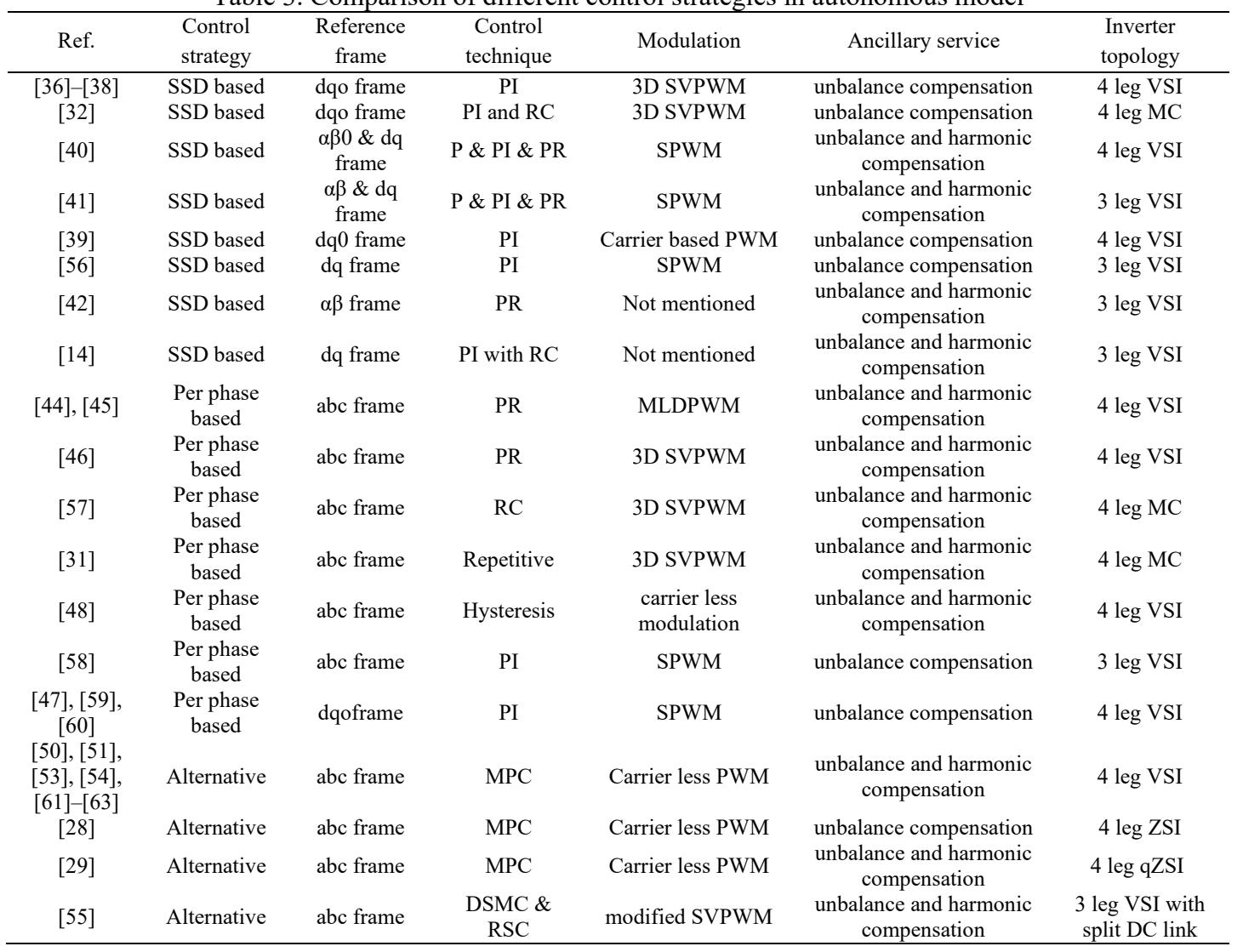

From the view of the control techniques, the PI controller in the synchronous frame is widely used and works well with pure DC signals relatively easy to implement. However, the PI controller suffers from some drawbacks including the presence of steady-state errors for non-dc signals, which limits the performance of the technique especially in the case of non-linear and unbalanced load applications. Moreover, the PI controller needs to decouple phase dependency in three phase systems. The PR controller is considered as an alternative method instead of the PI controller in the stationary and ABC reference frame as it has great ability to eliminate the steady-state error harmonic disturbances while regulating sinusoidal signals. Hence, it is greatly sensitive to system frequency variations.

$\mathrm{H} \infty$ has been applied to improve inverter robust stability under uncertainty and load disturbance. However, the control performance under nonlinear load is not satisfactory. Ho repetitive controller [64] can solve the problem but increase the complexity in the meantime. There is a growing interesting in using sliding mode control technique in inverter control due to its robustness and fast response. However, its dependence on knowledge of the control plant limits its application [55]. Predictive control gives an asymptotic tracking of controlled variables toward the corresponding references in the presence of disturbances, while it has some drawbacks such as its dependence on the system model and a lot of calculations are required. Repetitive control is used as a harmonic compensator as it eliminates periodical disturbance. However, its problem is addressed in its inherent slow response and lacking of the stability.

\section{CONCLUSION AND FUTURE RESEARCH SUGGESTIONS}

This paper has discussed the control of the three-phase inverters to compensate the load unbalances and harmonics. Two-level Inverter topologies for microgrids applications were presented in this paper. Furthermore, different control strategies for three-phase inverters under load unbalance condition were discussed, and their major characteristics were pointed out. Finally, detailed analysis, comparison, and discussion on these existing control strategies are investigated. This paper can be considered as a good reference for engineers and researchers working in the research area of control systems of autonomous voltage source inverters.

Int J Pow Elec \& Dri Syst, Vol. 10, No. 1, March 2019 : 242 - 255 
From the view of the previous publication's analysis, most of the control strategies are proposed for single-bus stand-alone microgrids, therefore further research is recommended that the area of the powersharing of unbalanced load needs more investigation in standalone microgrids. Furthermore, none of the used control techniques can be elected as a perfect solution to compensate all the power quality requirements, thus considerably more work is needed to be done to exploit new control strategies. To achieve better performance, it is necessary to use some innovative approaches such as artificial intelligence and robust control.

\section{REFERENCES}

[1] D. E. Olivares et al., "Trends in microgrid control," IEEE Trans. Smart Grid, vol. 5, no. 4, pp. 1905-1919, 2014.

[2] R. Zamora and A. K. Srivastava, "Controls for microgrids with storage: Review, challenges, and research needs," Renew. Sustain. Energy Rev., vol. 14, no. 7, pp. 2009-2018, 2010.

[3] O. Palizban and K. Kauhaniemi, "Hierarchical control structure in microgrids with distributed generation: Island and grid-connected mode," Renew. Sustain. Energy Rev., vol. 44, pp. 797-813, 2015.

[4] S. Obukhov, A. Ibrahim, and R. Aboelsaud, "Maximum Power Point Tracking OF Partially Shading PV system Using Particle Swarm Optimization," in Proceedings of the 4th International Conference on Frontiers of Educational Technologies - ICFET '18, pp. 161-165, 2018.

[5] T. L. Vandoorn, J. D. M. De Kooning, B. Meersman, and L. Vandevelde, "Review of primary control strategies for islanded microgrids with power-electronic interfaces,” Renew. Sustain. Energy Rev., vol. 19, pp. 613-628, 2013.

[6] M. Soshinskaya, W. H. J. Crijns-Graus, J. M. Guerrero, and J. C. Vasquez, "Microgrids: Experiences, barriers and success factors," Renew. Sustain. Energy Rev., vol. 40, pp. 659-672, 2014.

[7] M. M. M. El-Arini and R. S. S. Ahmed, "Optimal Location of Facts Devices To Improve Power Systems Performance," J. Electr. Eng., vol. 12, no. 3, 2012.

[8] N. Hatziargyriou, H. Asano, R. Iravani, and C. Marnay, "Microgrids," IEEE Power Energy Mag., vol. 5, no. 4, pp. 78-94, 2007.

[9] Y. Zhang, S. Zhang, P. Wang, L. Wang, and R. Zhang, "A Reference Compensation Current Control Strategy for Grid-Connected Inverter of Three-Phase Distributed Generators," TELKOMNIKA Indones. J. Electr. Eng., vol. 12, no. 5, pp. 3586-3594, 2014.

[10] T. Z. Khaing and L. Z. Kyin, "Control Analysis of Stand-Alone Wind Power Supply System with Three Phase PWM Voltage Source Inverter and Boost Converter," Int. J. Electr. Comput. Eng., vol. 5, no. 4, pp. $798-809,2015$.

[11] F. Shahnia, R. Majumder, A. Ghosh, G. Ledwich, and F. Zare, "Operation and control of a hybrid microgrid containing unbalanced and nonlinear loads," Electr. Power Syst. Res., vol. 80, no. 8, pp. 954-965, 2010.

[12] W. U. Tareen, S. Mekhilef, M. Seyedmahmoudian, and B. Horan, "Active power filter (APF) for mitigation of power quality issues in grid integration of wind and photovoltaic energy conversion system," Renew. Sustain. Energy Rev., vol. 70, no. December 2016, pp. 635-655, 2017.

[13] J. Rocabert, A. Luna, F. Blaabjerg, and P. Rodríguez, "Control of power converters in AC microgrids," IEEE Trans. Power Electron., vol. 27, no. 11, pp. 4734-4749, 2012.

[14] X. Liu, Y. Deng, Q. Liu, X. He, and Y. Tao, "Voltage unbalance and harmonics compensation for islanded microgrid inverters," IET Power Electron., vol. 7, no. 5, pp. 1055-1063, 2014.

[15] B. Meersman, B. Renders, L. Degroote, T. Vandoorn, J. De Kooning, and L. Vandevelde, "Overview of threephase inverter topologies for distributed generation purposes," Innov. Sustain. Prod. i-SUP 2010, pp. 24-28, 2010.

[16] D. Soto, C. Edrington, S. Balathandayuthapani, and S. Ryster, "Voltage balancing of islanded microgrids using a time-domain technique," Electr. Power Syst. Res., vol. 84, no. 1, pp. 214-223, 2012.

[17] P. K. Goel, B. Singh, S. S. Murthy, and N. Kishore, "Isolated wind-hydro hybrid system using cage generators and battery storage," IEEE Trans. Ind. Electron., vol. 58, no. 4, pp. 1141-1153, 2011.

[18] B. Axelrod, Y. Berkovich, and A. Ioinovici, "Increasing Voltage Utilization in Split-Link," Proc. 2003 Int. Symp. Circuits Syst. 2003. ISCAS '03., vol. 3, no. 6, pp. 1562-1569, 2003.

[19] M. K. Mishra, A. Joshi, and A. Ghosh, "Control schemes for equalization of capacitor voltages in neutral clamped shunt compensator," IEEE Trans. Power Deliv., vol. 18, no. 2, pp. 538-544, 2003.

[20] A. Hintz, U. R. Prasanna, and K. Rajashekara, "Comparative Study of the Three-Phase Grid-Connected Inverter Sharing Unbalanced Three-Phase and/or Single-Phase systems," IEEE Trans. Ind. Appl., vol. 52, no. 6, pp. 5156-5164, 2016.

[21] V. Khadkikar and A. Chandra, "An independent control approach for three-phase four-wire shunt active filter based on three H-bridge topology under unbalanced load conditions," PESC Rec. - IEEE Annu. Power Electron. Spec. Conf., pp. 4643-4649, 2008.

[22] R. Omar, M. Rasheed, M. Sulaiman, and M. R. Tamijis, "Comparative Study of a Three Phase Cascaded HBridge Multilevel Inverter for Harmonic Reduction," TELKOMNIKA Indones. J. Electr. Eng., vol. 14, no. 3, pp. 481-492, 2015.

[23] M. R. Miveh, M. F. Rahmat, A. A. Ghadimi, and M. W. Mustafa, "Control techniques for three-phase four-leg voltage source inverters in autonomous microgrids: A review," Renew. Sustain. Energy Rev., vol. 54, pp. 1592-1610, 2016.

[24] F. V. Converters, R. Zhang, V. H. Prasad, D. Boroyevich, and F. C. Lee, "Three-Dimensional Space Vector 
Modulation for for Four-Leg Voltage-Source Converters," IEEE Trans. POWER Electron., vol. 17, no. 3, pp. 314-326, 2002.

[25] W. Qian, F. Z. Peng, and H. Cha, "Trans-Z-Source Inverters," vol. 26, no. 12, pp. 3453-3463, 2011.

[26] D. Kumar and Z. Husain, "A Comparative Study of Z-Source Inverter Fed Three-Phase IM Drive with CSI and VSI fed IM,” Int. J. Power Electron. Drive Syst., vol. 3, no. 3, pp. 259-270, 2013.

[27] P. Fang Zheng and F. Z. Peng, “Z-Source Inverter," IEEE Trans. Ind. Appl., vol. 39, no. 2, pp. 504-510, 2003.

[28] C. Paper, S. B. Texas, and M. T. Texas, "Model Predictive Control of Z-Source Four-Leg Inverter for Standalone Photovoltaic System with Unbalanced Load," IEEE Trans., no. March, pp. 3663-3668, 2016.

[29] S. Bayhan, M. Trabelsi, H. Abu-Rub, and M. Malinowski, "Finite Control Set Model Predictive Control for a Quasi-Z-Source Four-Leg Inverter Under Unbalanced Load Condition,” IEEE Trans. Ind. Electron., vol. 0046, no. c, pp. 1-1, 2016

[30] M. Hussein, T. Senjyu, M. Orabi, M. Wahab, and M. Hamada, "Control of a Stand-Alone Variable Speed Wind Energy Supply System †," Appl. Sci., vol. 3, no. 2, pp. 437-456, 2013.

[31] R. Cárdenas, R. Peña, J. Clare, P. Wheeler, and P. Zanchetta, "A repetitive control system for four-leg matrix converters feeding non-linear loads," Electr. Power Syst. Res., vol. 104, pp. 18-27, 2013.

[32] R. Cárdenas, R. Peña, P. Wheeler, J. Clare, and C. Juri, "Control of a matrix converter for the operation of autonomous systems," Renew. Energy, vol. 43, pp. 343-353, 2012.

[33] M. Matteini, "Fundamentals of Matrix Converter," PhD Thesis, pp. 15-29, 2001.

[34] T. Friedli, J. W. Kolar, J. Rodriguez, and P. W. Wheeler, "Comparative evaluation of three-phase AC-AC matrix converter and voltage DC-link back-to-back converter systems," IEEE Trans. Ind. Electron., vol. 59, no. 12, pp. 4487-4510, 2012.

[35] C. Hochgraf and R. H. Lasseter, "Statcom controls for operation with unbalanced voltages," IEEE Trans. Power Deliv., vol. 13, no. 2, pp. 538-544, 1998.

[36] I. Vechiu, H. Camblong, G. Tapia, B. Dakyo, and O. Curea, "Control of four leg inverter for hybrid power system applications with unbalanced load," Energy Convers. Manag., vol. 48, no. 7, pp. 2119-2128, 2007.

[37] I. Vechium and H. Camblong, "Modelling and control of four-wire voltage source inverter under unbalanced voltage condition for hybrid power system applications," Eur. Conf. Power Electron. Appl., no. 1, pp. 1-10, 2005.

[38] B. Axelrod, Y. Berkovich, and A. Ioinovici, "Transient Operation of a Four-Leg Inverter for Transient Operation of a Four-Leg Inverter for Autonomous ApplicationsWith Unbalanced Load,” Proc. 2003 Int. Symp. Circuits Syst. 2003. ISCAS '03., vol. 3, no. 2, pp. 399-407, 2003.

[39] G. H. Kim, C. Hwang, J. H. Jeon, G. S. Byeon, J. B. Ahn, and C. H. Jo, "A novel three-phase four-leg inverter based load unbalance compensator for stand-alone microgrid," 9th Int. Conf. Power Electron. - ECCE Asia "Green World with Power Electron. ICPE 2015-ECCE Asia, vol. 65, pp. 1491-1496, 2015.

[40] Li Y,VilathgamuwaDM and P. C. Loh, "Microgrid Power Quality Enhancement Using a Three-Phase Four-Wire," IEEE Trans. Ind. Appl., vol. 41, no. 6, pp. 1707-1719, 2005.

[41] L. P. Li YW, Vilathgamuwa DM, “A Grid-Interfacing Power Quality Compensator for Three-Phase Three-Wire Microgrid Applications," vol. 21, no. 4, pp. 1021-1031, 2006.

[42] L. Xu, Z. Miao, and L. FAn, "Unbalance and Harmonic Mitigation Using Battery Inverters," North Am. Power Symp. (NAPS), 2015.

[43] F. Blaabjerg, R. Teodorescu, M. Liserre, and A. V. Timbus, "Overview of control and grid synchronization for distributed power generation systems,” IEEE Trans. Ind. Electron., vol. 53, no. 5, pp. 1398-1409, 2006.

[44] E. Demirkutlu and A. M. Hava, "A scalar resonant-filter-bank-based output-voltage control method and a scalar minimum-switching-loss discontinuous PWM method for the four-leg-inverter-based three-phase four-wire power supply,” IEEE Trans. Ind. Appl., vol. 45, no. 3, pp. 982-991, 2009.

[45] A. M. Hava and E. Demirkutlu, "Output voltage control of a four-leg inverter based three-phase UPS," 2007 Eur. Conf. Power Electron. Appl., no. Dc, pp. 880-885, 2007.

[46] T. Glasberger and Z. Peroutka, "Control of power supply unit for military vehicles based on four-leg three-phase VSI with proportional-resonant controllers," 2008 13th Int. Power Electron. Motion Control Conf. EPE-PEMC 2008, pp. 1268-1273, 2008.

[47] N. A. Ninad and L. Lopes, "Per-phase vector control strategy for a four-leg voltage source inverter operating with highly unbalanced loads in stand-alone hybrid systems," Int. J. Electr. Power Energy Syst., vol. 55, pp. 449-459, 2014.

[48] X. Zhang, J. Wang, and C. Li, "Three-phase four-leg inverter based on voltage hysteresis control," in Proceedings IEEE- International Conference on Electrical and Control Engineering, ICECE 2010, 2010, pp. 4482-4485.

[49] M. Monfared and S. Golestan, "Control strategies for single-phase grid integration of small-scale renewable energy sources: A review," Renew. Sustain. Energy Rev., vol. 16, no. 7, pp. 4982-4993, 2012.

[50] V. Yaramasu, M. Rivera, B. Wu, and J. Rodriguez, "Model Predictive Current Control of Two-Level Four-Leg Inverters-Part I: Concept, Algorithm, and Simulation Analysis," Ieee Trans. Power Electron., vol. 28, no. 7, pp. 3459-3468, 2013.

[51] M. Rivera, V. Yaramasu, A. Llor, J. Rodriguez, B. Wu, and M. Fadel, "Digital predictive current control of a threephase four-leg inverter," IEEE Trans. Ind. Electron., vol. 60, no. 11, pp. 4903-4912, 2013.

[52] S. Bayhan, H. Abu-Rub, and R. S. Balog, "Model Predictive Control of Quasi-Z-Source Four-Leg Inverter," IEEE Trans. Ind. Electron., vol. 63, no. 7, pp. 4506-4516, 2016.

[53] V. Yaramasu, S. Member, M. Rivera, M. Narimani, B. Wu, and J. Rodriguez, "Model Predictive Approach for a Simple and Effective Load Voltage Control of Four-Leg Inverter With an Output LC Filter," IEEE Trans. Ind.

Int J Pow Elec \& Dri Syst, Vol. 10, No. 1, March 2019 : 242 - 255 
Electron., vol. 61, no. 10, pp. 5259-5270, 2014.

[54] A. G. Garganeev, R. Aboelsaud, and A. Ibrahim, "A Novel Predictive Control Algorithm For Autonomous Power Supply Systems," in Proceedings of the 4th International Conference on Frontiers of Educational Technologies ICFET '18, 2018, pp. 170-175.

[55] M. Dai, M. N. Marwali, J. W. Jung, and A. Keyhani, "A three-phase four-wire inverter control technique for a single distributed generation unit in Island mode," IEEE Trans. Power Electron., vol. 23, no. 1, pp. 322-331, 2008.

[56] M. Hojo, Y. Iwase, T. Funabashi, and Y. Ueda, "A method of three-phase balancing in microgrid by photovoltaic generation systems," 2008 13th Int. Power Electron. Motion Control Conf. EPE-PEMC 2008, pp. 2487-2491, 2008.

[57] R. Cárdenas, C. Juri, R. Peña, P. Wheeler, and J. Clare, "The application of resonant controllers to four-leg matrix converters feeding unbalanced or nonlinear loads," IEEE Trans. Power Electron., vol. 27, no. 3, pp. 1120-1129, 2012.

[58] S. G. Malla and C. N. Bhende, "Voltage control of stand-alone wind and solar energy system," Int. J. Electr. Power Energy Syst., vol. 56, pp. 361-373, 2014.

[59] N. A. Ninad and L. A. C. Lopes, "Per-phase vector (dq) controlled three-phase grid-forming inverter for standalone systems," Proc. - ISIE 20112011 IEEE Int. Symp. Ind. Electron., pp. 1626-1631, 2011.

[60] N. A. Ninad and L. A. C. Lopes, "Unbalanced operation of per-phase vector controlled four-leg grid forming inverter for stand-alone hybrid systems," IECON Proc. (Industrial Electron. Conf., pp. 3500-3505, 2012.

[61] J. Rodriguez, B. Wu, M. Rivera, C. Rojas, V. Yaramasu, and A. Wilson, "Predictive current control of three-phase two-level four-leg inverter," Proc. EPE-PEMC 2010 - 14th Int. Power Electron. Motion Control Conf., pp. 106-110, 2010.

[62] V. Yaramasu, B. Wu, M. Rivera, and J. Rodriguez, "Enhanced model predictive voltage control of four-leg inverters with switching frequency reduction for standalone power systems," 15th Int. Power Electron. Motion Control Conf. Expo. EPE-PEMC 2012 ECCE Eur., no. 3, pp. 1-5, 2012.

[63] V. Yaramasu, J. Rodriguez, B. Wu, M. Rivera, A. Wilson, and C. Rojas, "A simple and effective solution for superior performance in two-level four-leg voltage source inverters: Predictive voltage control," IEEE Int. Symp. Ind. Electron., pp. 3127-3132, 2010.

[64] T. Hornik and Q. C. Zhong, "Hळ repetitive current-voltage control of inverters in microgrids," in IECON Proceedings (Industrial Electronics Conference), pp. 3000-3005, 2010. 